\title{
Detection of Potential Areas to Prone Flood in Luwu Utara Regency, Indonesia
}

\author{
Muhammad Ichsan Ali \\ Faculty of Engineering, Universitas Negeri Makassar, Indonesia
}

\begin{abstract}
The purpose of this research is to know the potential area of flood prone in Luwu Utara Regency. This study used the descriptive qualitative method. The technique of collecting data done through survey method that is the first survey is observation or observation object, and the second review is through a study of institution and study of the document which analyzed qualitatively. The method of analysis used to obtain flood vulnerability that is data analysis using overlay technique with rock Geographic Information System technology. North Luwu Regency has four classes of potential flood-prone. As for the other factors that cause some districts in Luwu Utara District to be prone to flood is because the District has a bad drainage level (very close basin level), then other factors are the area is also passed by two watersheds.
\end{abstract}

Keywords: Potential of Flood Prone, Geographic Information System, Watershed

\section{Introduction}

The high impact of flooding on society has focused attention on rainfall extremes of different durations. A yearly report assesses many observed extremes in the context of background climate variability and changes applicable for their location [1]. Over many land regions, including the midlatitudes, measurements indicate an increased frequency of intense rainfall events, in agreement with climate model estimates [2]. Another problem is the use of temporally dynamic processes, which are considered a major obstacle when coupling a GIS with environmental modeling [3].

Flooding in floodplains and alluvial plains is an important issue, given the concentration of the majority settlements in the region. If the area flooded, it would cause enormous losses such as loss of life, public infrastructure damage, personal damage to the material of the population, and the disruption of the city's economy which will eventually cause harm and misery to the people affected by the floods.

One of the areas vulnerable to floods is the northern Luwu regency. Due to the geomorphology of the North Luwu regency, in particular, the coastal zone is a flood plain area with a topographic state of $<8 \%$, especially in coastal zones through more than ten rivers, With the largest and longest river, is salt rongkong. The sectors that include flood plain areas are Malangke, Malangke Barat, Bone-Bone, Baebunta, Sabbang which are densely populated areas that are very vulnerable to floods, so that in the case of flooding it will cause massive losses.

The hydrological analysis itself is often hampered by limited data of adequate quality and lacks real-time data, which are fundamental to the success of any flood forecasting system [4]. For example, found that reduced flooding reduced the prevalence of roundworm and hookworm by a factor of two and hookworm alone by a factor of three [5].

Last, but not least, parasites seem to thrive when urban flooding occurs regularly. Moist soil provides an excellent environment for worm eggs to flourish, and water flooding open drains spread eggs to new victims [6]. Many cities located too high and coastal deltaic settlements vulnerable to flooding due to the criticism of their proximity to the rivers and the sea, therefore general Low land subsidence and elevations [7] [8].

Floods are floods or puddles from rivers or other bodies of water caused by excessive rainfall or melting snow, or it could be due to tidal waves flooding mostly on floodplains [9]. Flooding is resulting from several factors, namely rain factor, destruction factor of Watershed (DAS), an erroneous factor of river channel development planning, river silting factor, and environmental fault factor and development of facilities and infrastructure. Based on these problems, it is necessary to take action to reduce the loss, one effort that can do is the determination of flood prone areas in North Luwu District

\section{Method}

This study used a descriptive qualitative method. The research method chosen because the research that will do more leads to the disclosure of a problem or circumstance and reveal the facts that exist. The technique of collecting data done by survey method that is the first study is observation or observation object, and a secondary review is through a survey to institution and study of the document which analyzed qualitatively as for the variables in this study are:

- Classification of soil

- Infiltrating slope

- Field Land use

- Annual rainfall

The analytical method used to obtain flood vulnerability, i.e., data analysis using overlay technique of flood parameters which each parameter was scored to get flood vulnerability zonation. Overlapping did with rock Geographic Information 


\section{International Journal of Science and Research (IJSR) \\ ISSN (Online): 2319-7064}

Index Copernicus Value (2015): 78.96 | Impact Factor (2015): 6.391

System technology.

The weighting of each parameter or variable varies depending on how much influence these parameters have on the occurrence of floods. The greater the influence of these parameters on the flood then the value of weight is also large; otherwise, if the effect is small then the amount of weight is also small.

Arithmetic methods used in the overlay process can be additions, excavations, and powers. For the manufacture of Flood Vulnerability Map calculation method employed in the overlay process of flood vulnerability parameters in the form of the means of harnessing the harvest with the weight of each flood vulnerability parameter.

Arithmetic methods used in the overlay process can be additions, excavations, and powers. For the manufacture of Flood Vulnerability Map calculation method utilized in the overlay process of flood vulnerability parameters in the form of the means of harnessing the harvest with the weight of each flood vulnerability parameter.

Table 1: Class Division Rate of Flood Vulnerability

\begin{tabular}{|c|l|r|}
\hline No & \multicolumn{1}{|c|}{ Level of Insecurity } & Score \\
\hline 1 & Very vulnerable & $>56-70$ \\
\hline 2 & Prone & $>42-56$ \\
\hline 3 & Less vulnerable & $>28-42$ \\
\hline 4 & Not vulnerable & $14-28$ \\
\hline
\end{tabular}

The relative approach determines the interval value by looking at the maximum value and minimum value of each mapping unit, the range class, is obtained by finding the difference between the highest data and the lowest data and divided by the desired number of levels. The flood vulnerability in this study divided into five classes of vulnerability levels, which are highly vulnerable, sensitive, moderately vulnerable, somewhat vulnerable and not vulnerable

\section{Result and Discussion}

North Luwu regency is one of the districts in the southern part of South Sulawesi which is approximately $240 \mathrm{Km}$ from the capital of South Sulawesi Province located between $01^{\mathrm{O}}$ 53 '019 - 02 $52^{\mathrm{O}} 36$ "South Latitude (LS) and $119^{\circ} 47$ '44" East Longitude (BT) with administrative boundaries:

- North: Bordered by Central Sulawesi

- South: Bordering Luwu Regency and Bone Bay

- West side: Bordered by West Sulawesi Province

- East: Adjacent to East Luwu

The total area of North Luwu Regency is about 7,843.57 $\mathrm{Km} 2$ divided into 12 districts covering 173 villages consisting of 4 urban villages and 169 villages. And eight major rivers irrigate the area of North Luwu Regency. The longest river is the Rongkong river with a length of $108 \mathrm{Km}$ [10].
The potential flood area based on scoring is obtained based on spatial analysis on slope map, daily rainfall map, soil type map based on infiltrating condition and land use classification map. Here are the maps:

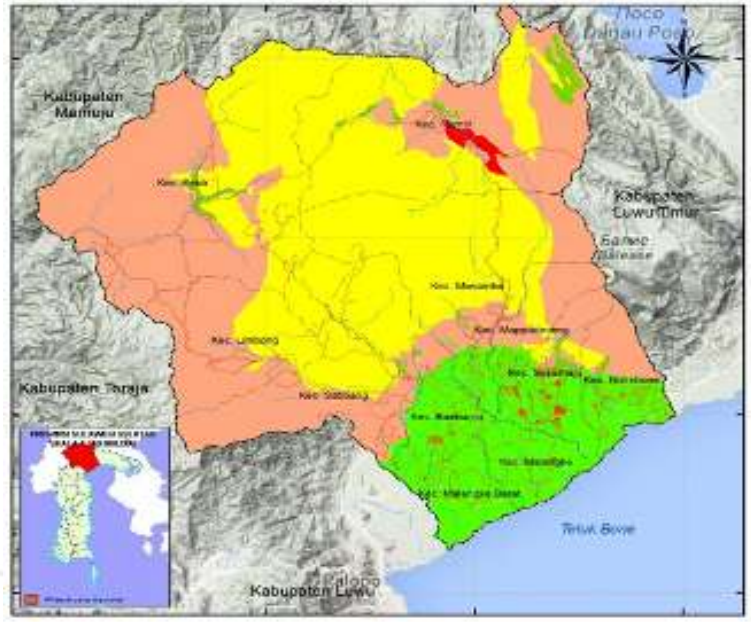

Figure 1: Map of Soil Type (infiltration)

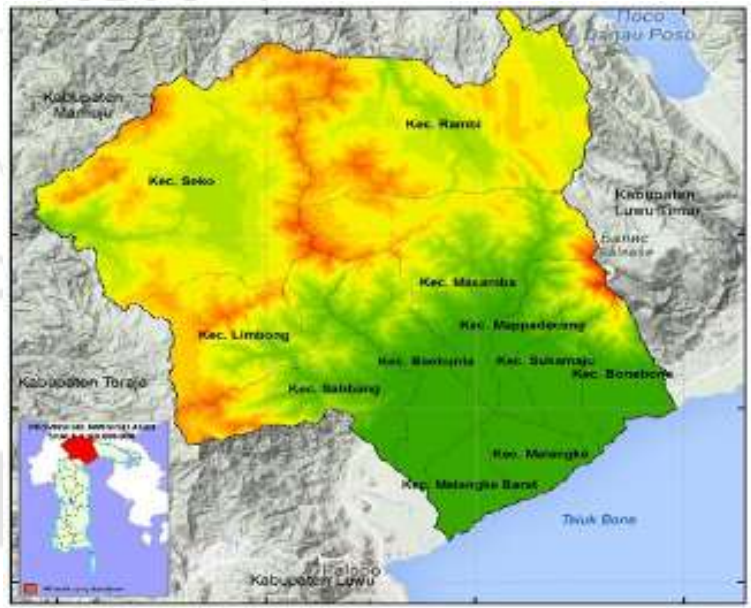

Figure 2: Slope Map Slope

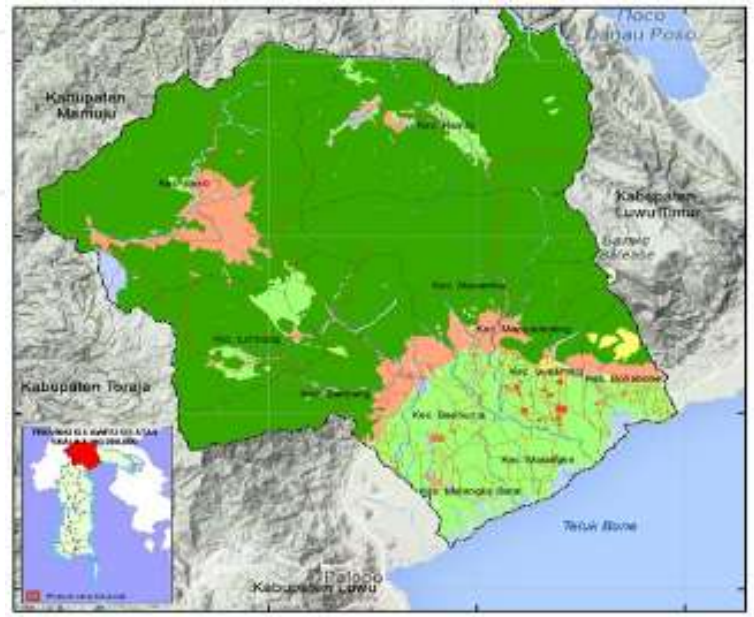

Figure 3: Map of Land Use 


\section{International Journal of Science and Research (IJSR) ISSN (Online): 2319-7064}

Index Copernicus Value (2015): 78.96 | Impact Factor (2015): 6.391

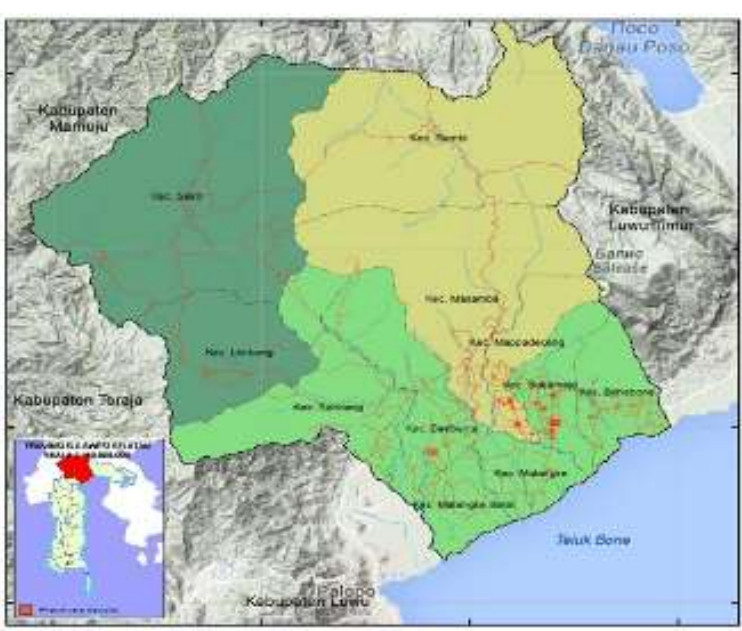

Figure 4: Map of Annual Rainfall

The flood potential map that has been created based on the determinants of flood potential indicates that Luwu Utara District consists of four classes of flood vulnerability that are very vulnerable, prone, less vulnerable and not vulnerable.

The percentage and table of an area of a potential flood in Luwu Utara Regency can see in the following figure and table:

Table 2: Percentage of Potential Areas of Flood in North Luwu Regency

\begin{tabular}{|c|c|c|c|}
\hline No & Level of Insecurity & $\begin{array}{c}\text { Large } \\
(\mathrm{Ha})\end{array}$ & $\begin{array}{c}\text { Percentage } \\
(\%)\end{array}$ \\
\hline 1 & Not vulnerable & 9.608 .95 & 12.25 \\
\hline 2 & Less vulnerable & 23.371 .18 & 29.79 \\
\hline 3 & Prone & 29.608 .53 & 37.75 \\
\hline 4 & Very vulnerable & 15.846 .32 & 20.21 \\
\hline & Total & 78.435 & 100.00 \\
\hline
\end{tabular}

Based on the percentage and the area of flood potential in Luwu Utara Regency. The total area of administrative area of Luwu Utara Regency is $78.435 \mathrm{Ha}$, with flood prone area of $15,846.32 \mathrm{Ha}$, prone to flood that is $29.608 .55 \mathrm{Ha}$, less vulnerable that is $32.371 .18 \mathrm{Ha}$, And the area is not sensitive, i.e., 9,608.95 Ha. The map of the level of flood-prone potential in North Luwu Regency can be seen in Figure 1.7 below:

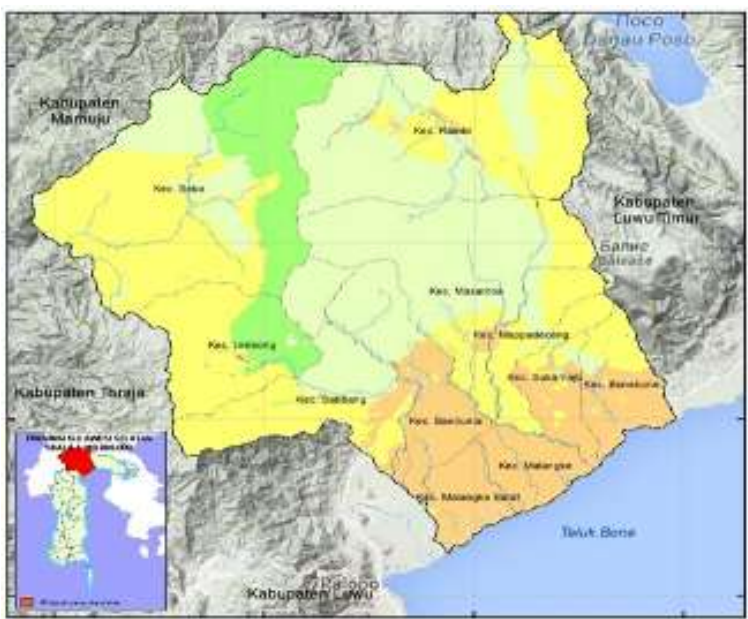

Figure 5: Map of Potential Areas of Flood
Table 3: Flood Potential Based on Division of Region in Luwu Utara Regency

\begin{tabular}{|c|c|c|c|c|c|}
\hline \multirow{2}{*}{ No } & Districts & \multicolumn{4}{|c|}{ Potential Flood (Ha) } \\
\cline { 2 - 6 } & & $\begin{array}{c}\text { Not } \\
\text { Prone }\end{array}$ & $\begin{array}{c}\text { Less } \\
\text { Prone }\end{array}$ & Prone & $\begin{array}{c}\text { Very } \\
\text { Prone }\end{array}$ \\
\hline 1 & Seko & $\begin{array}{c}8.304 .4 \\
0\end{array}$ & 1.768 .5 & 9.076 .12 & - \\
\hline 2 & Rampi & - & 6.163 .2 & 4.100 .1 & - \\
\hline 3 & Masamba & - & 8.683 .6 & 1.284 & - \\
\hline 4 & $\begin{array}{c}\text { Mappedecen } \\
\text { g }\end{array}$ & - & 781.2 & 3.842 .5 & 120.9 \\
\hline 5 & Sukamaju & - & 120 & 1.821 .11 & 1.060 .6 \\
\hline 6 & Bone Bone & - & 180 & 623.20 & 1.100 .2 \\
\hline 7 & Baebunta & - & 1.630 .1 & - & 2.154 .6 \\
\hline 8 & Sabbang & - & 4.046 .2 & 4.432 .6 & 846.2 \\
\hline 9 & Malangke & - & - & - & 5.460 .3 \\
\hline 10 & Limbong & 1.304 .5 & - & 5.421 .8 & - \\
\hline 11 & $\begin{array}{c}\text { Malangke } \\
\text { Barat }\end{array}$ & - & - & - & 5.106 .4 \\
\hline & Total & 9.608 .9 & 23.371 .8 & 29.608 .5 & 15.846 .3 \\
& & 5 & 1 & 5 & 2 \\
\hline
\end{tabular}

The area that has the potential to be very vulnerable to flood is $15,846.32 \mathrm{Ha}$ or $20.21 \%$ of the total area of Luwu Utara Regency; then the area coverage is Malangke District $(5,460.3 \mathrm{Ha})$, Malangke Barat Subdistrict $(5,106.4 \mathrm{Ha})$, and Baebunta Sub-district (2.154.6). Sectors that have the potential to be particularly vulnerable to flooding because of their topographical features $<8 \%$, soil infiltration conditions are rather rapid, annual rainfall $>3000 \mathrm{~mm} \mathrm{/} \mathrm{year,} \mathrm{and}$ dominant land use agriculture, rice fields, open land, swamps.

The area with flood-prone areas is $29.608 .55 \mathrm{Ha}$ or $37.75 \%$ of the total area of Luwu Utara Regency, while the area is Seko sub-district (9.076.12), Sabbang sub-district (4.432.6), Mappedeceng sub-district (3,842. 5) and Limbong Subdistrict (5.421.8). Sectors that have flood-prone potential because this region is an area located in the watershed area of the major rivers, so it is prone to flooding when the rainy season occurs.

The area with less flood potential is $23.371 .18 \mathrm{Ha}$ or $29.79 \%$ of the total area of Luwu Utara Regency, while the coverage area is Rampi (6.163.2) and Masamba sub district $(8,683.6)$. Sectors that have less vulnerable potential because this field has a grade of slope II or $8-15 \%$, little rainfall, then the dominant land use of plantation and forest subsequent rate of soil infiltrating very slowly namely Grumusol.

The area with non-vulnerable potential is 9.608 .95 or $12.25 \%$ of the total area of North Luwu Regency, while the scope area is part of Seko and Limbong Sub-districts, this is because the area partly classed above $25 \%$ With a slow rate of soil infiltration and little rainfall than the dominant use of the primary forest.

The other factors that cause some sub-districts in Luwu Utara District to be prone to flood are because the sub-district has a bad drainage level (very close basin level), then another factor is that the area also passed by two watersheds Das Salu Rongkong and Das Salu Uraso whose tributary flows boils down the Bone Strait. For more details about the state of

Volume 6 Issue 8, August 2017 www.ijsr.net

Licensed Under Creative Commons Attribution CC BY 


\section{International Journal of Science and Research (IJSR) \\ ISSN (Online): 2319-7064}

Index Copernicus Value (2015): 78.96 | Impact Factor (2015): 6.391

drainage and the state of DAS in North Luwu regency can be seen in the following figure:

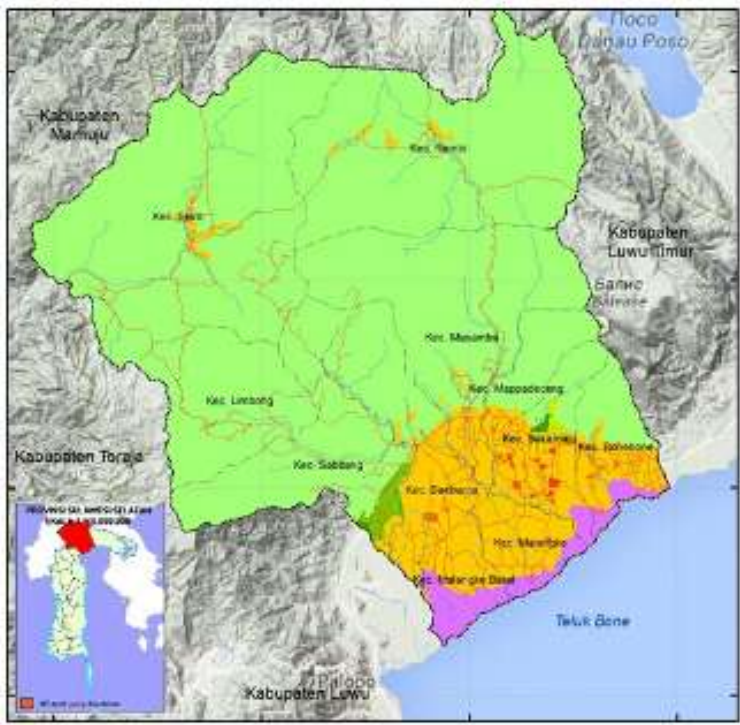

Figure 6: Map of Drainage Conditions

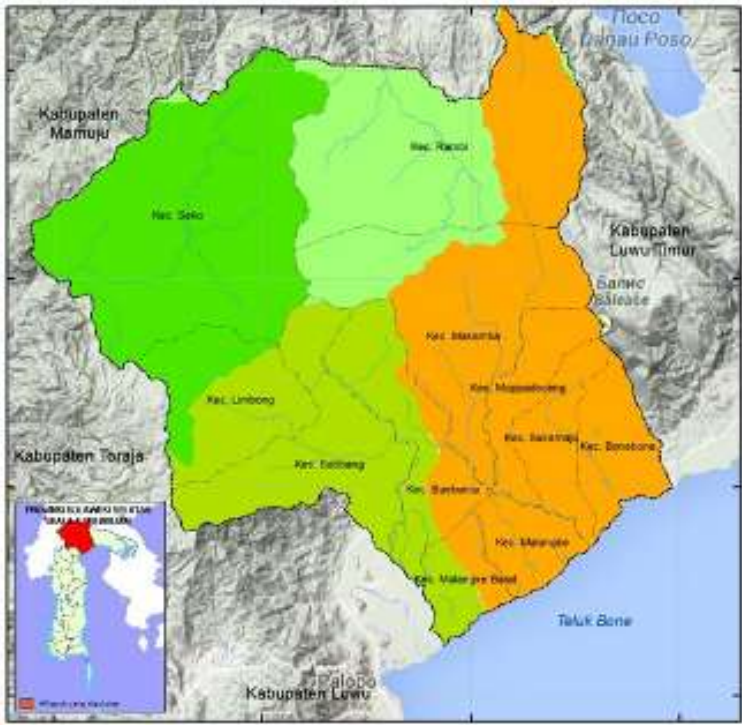

Figure 7: Map of the watershed

The North Luwu regency has four basins, with the largest watershed is the salt reason river, and has more than ten rivers, with the biggest and longest river is Salu Rongkong with $\pm 100 \mathrm{Km}$ length which boils down to the bone bay. Then the level of drainage for Malangke, North Malangke, Baebunta and some areas of Sukamaju and Bone-Bone have poor drainage conditions, while in Sabbang, Limbong, Seko, Rampi, Masamba, and Mappedeceng sub-districts have good drainage conditions.

\section{Conclusion}

The total administrative area of Luwu Utara Regency is 78.435 Ha. North Luwu Regency has four classes of potential flood prone areas, namely flood prone areas are 15,846.32 $\mathrm{Ha}$, flood prone of $29,608,55 \mathrm{Ha}$, less vulnerable that is 32.371.18 $\mathrm{Ha}$, and the area is not sensitive that is 9608.95 Ha. The other factors causing the flood potential in Luwu
Utara Regency are the dangerous condition of Drainage, especially in lowland and coastal areas, then North Luwu Regency has 4 watershed areas, where 2 basins located in Bone bay, with River The largest and longest is the Rongkong River through Baebunta, Sabbang, Malangke and North Malangke Subdistricts.

\section{References}

[1] Peterson, Thomas C., Hoerling, Martin P., P. A. Stott, and S. C. Herring, "Explaining extreme events of 2012 from a climate perspective," Bull. Am. Meteorol. Soc., vol. 94, no. 9, pp. S1--S74, 2013.

[2] P. Y. Groisman, R. W. Knight, D. R. Easterling, T. R. Karl, G. C. Hegerl, and V. N. Razuvaev, "Trends in intense precipitation in the climate record," J. Clim., vol. 18, no. 9, pp. 1326-1350, 2005.

[3] J. Albrecht, S. Jung, and S. Mann, "VGIS: a GIS shell for the conceptual design of environmental models," Innov. GIS, vol. 4, pp. 154-165, 1997.

[4] A. Goonetilleke and G. A. Jenkins, "The role of geographical information systems in urban hydrological modelling," Water Environ. J., vol. 13, no. 3, pp. 200-206, 1999.

[5] Moraes, Luiz Robertos Santos., "Health impact of drainage and sewerage in poor urban areas in Salvador, Brazil.," Dissertation, University of London, 1996.

[6] Kolsky, Pete., "Storm Drainage: An engineering guide to the low-cost evaluation of system performance," Intermed. Technol. Publ. Ltd. London, p. 134, 1998.

[7] Nicholls, Robert J. et al., "Ranking port cities with high exposure and vulnerability to climate extremes," Exposure Estimates. OECD Publishing, Paris, France, p. 62, 2008.

[8] Syvitski, James P M. et al., "Sinking deltas due to human activities," Nat. Geosci., vol. 2, no. 10, p. 681, 2009.

[9] L. Soemantri, "Pemanfaatan Teknik Penginderaan jauh untuk mengidentifikasi kerentanan dan risiko banjir," J. Geogr. Geogr., vol. 8, no. 2, 2016.

[10] Badan Pusat Statistik, Kabupaten Luwu Utara Dalam Angka. Luwu Utara, 2013. 